\title{
Altered cannabinoid receptor expression in pancreatic islets in experimental model of uraemia
}

\author{
P. Nowińska, M. Niezgoda, N. Domian, I. Kasacka \\ Department of Histology and Cytophysiology, Medical University of Bialystok, Poland \\ [Received: 8 July 2019; Accepted: 21 September 2019]
}

\begin{abstract}
Background: Uraemia leads to a number of metabolic and hormonal disorders including defective carbohydrate metabolism. Endocannabinoids exert their effect on insulin and glucagon secretion via activation of specific receptors named CB1 and CB2. For this reason and the absence of reports on location and immunoreactivity of CB1, CB2 receptors compared to immunoreactivity of insulin- and glucagon-secreting cells in experimental uraemia, the author decided to investigate this issue. The aim of the present study was the immunohistochemical localisation and evaluation of cannabinoid receptors (CB1, CB2), insulin and glucagon in the pancreatic islets of uraemic rats.

Materials and methods: Fragments of the rat's pancreas were collected 28 days after surgical resection of one kidney and removal of $70 \%$ of the other kidney cortex. Paraffin-embedded sections were stained with haematoxylin-eosin and immunohistochemical reactions were performed with the use of a specific antibody against CB1-, CB2-receptors, insulin and glucagon.

Results: It was revealed the decreased immunoreactivity of the $C B 1$ receptor and higher intensity of the immunohistochemical reaction against CB2 receptor as compared to the value in the control animals. Significantly higher immunoreactivity of glucagon-positive cells and weaker immunoreactivity of insulin-positive cells were observed in pancreatic islets of uraemic rats.

Conclusions: The obtained results indicate the involvement of cannabinoid receptors in the pathomechanism of carbohydrate metabolism disorders, associated with abnormal secretion of hormones by the $\alpha$ and $\beta$ cells in uraemia. (Folia Morphol 2020; 79, 3: 469-475)
\end{abstract}

Key words: pancreatic islets, cannabinoid receptor, uraemia, rat

\section{INTRODUCTION}

It is well known that chronic renal failure results in disorders of many organs and systems including carbohydrate metabolism $[2,3,15]$. Recent studies indicate a close functional relationship between the endocannabinoid system and hormones related to maintaining the energy and metabolic balance $[18,23,30,33]$.
Due to the presence of $\mathrm{CB} 1$ and $\mathrm{CB} 2$ receptors in pancreatic islet cells, endocannabinoids are involved in the regulation of insulin and glucagon $[1,5,6,22$, 35]. Several reports indicate that using CB1 receptor antagonist results in impaired insulin secretion and administration of an agonist leads to increased insulin secretion in rats $[11,13,22]$. Similar observations

Address for correspondence: Prof. I. Kasacka, Department of Histology and Cytophysiology, Medical University of Bialystok, ul. Mickiewicza 2C, 15-222 Białystok, Poland, tel: +85 74854 58; fax: +85 74855 16, e-mail: kasacka@umb.edu.pl 
have been made on patients treated with a CB1 receptor agonist [7]. Other studies on mice have shown a decrease in insulin secretion following CB1 receptor activation [28].

It has been proven in experimental conditions that following the use of streptozotocin, $\beta$ cell survival increases in animals with a pharmacological blockade or a genetic deficiency in the CB1 receptor. The same experiment revealed that the activation of this receptor induces the death of $\beta$ cells in an insulin receptor-dependent manner [19].

Recent reports indicate the presence of autonomous endocannabinoid system in the endocrine pancreas and emphasize important role of CB1 receptors in $\beta$ cells. In addition, the participation of $\alpha$ pancreatic islet cells in the synthesis of endocannabinoids and $\beta$ cells in the synthesis of enzymes degrading endocannabinoids has been demonstrated [7, 25, 26]. Activation of CB1 receptors by cannabinoids produced in $\alpha$ cells may lead to an increase in insulin secretion in $\beta$ cells [25].

Endocannabinoids are synthesized on demand from derivatives of arachidonic acid bounded to membrane. After action, the endocannabinoids are rapidly degraded by specific enzymes and products are recycled. CB1 and CB2 are G-protein coupled receptors and inhibit activation of adenyl cyclase (AC) and CAMP-PKA activity as well as activate MAPK. In addition, CB1 receptor inhibits voltage-gated L-, N- and P/Q-type $\mathrm{Ca}^{2+}$ channels and inwardly correcting $\mathrm{K}^{+}$channels [14].

There are many pathways activated by the CB1 and $C B 2$ receptors associated with the secretion and survival of pancreatic islet cells. CB1 receptor may induce activation of an inwardly rectifying $\mathrm{K}^{+}$channel, resulting in decrease excitability and inhibition of voltage gated calcium channel and inhibition of $\mathrm{Ca}^{2+}$ influx. Activated $\mathrm{CB} 1$ or $\mathrm{CB} 2$ receptor leads to the activation of $p 38$ and p42/44 mitogen activated protein kinases (MAPKs). The P38 isoforms of MAPK can activate caspases and induce apoptosis, on the other hand $\mathrm{p} 42 / \mathrm{p} 44$ stimulates cellular proliferation. Gi/o activation evoked by $C B 1$ and $C B 2$ receptors indicates $A C$ inhibition and subsequent reductions in cyclic AMP (CAMP). Under certain circumstances $\mathrm{CB} 1$ receptors may increases $\mathrm{Ca}^{2+}$ influx induced by stimulation $A C$ via Gs and the increased CAMP, then it can activates protein kinase $A$ and result in phosphorylation of VGCCs. Calcium level may be elevated also by activation of phospholipase $\mathrm{C}$ via another pathway related with $\mathrm{CB} 1$ receptor. Entry into this pathway may also result in stimulation of cellular proliferation [23].

It is well known that renal failure leads to the accumulation of many toxic substances such as urea or reactive oxygen species which can impair the function and impact on the survival of a number of cell types inducing their apoptosis $[20,29,34]$.

In the current literature there is a lack of reports concerning cannabinoid receptors in the pancreatic islet area in uraemia.

The aim of the study was the immunohistochemical localisation of CB1, CB2 cannabinoid receptors and insulin-, glucagon-secreting cells in the pancreas of uraemic rats.

\section{MATERIALS AND METHODS}

\section{Experimental animals}

The study was performed on 15 young male Wistar rats, their body weight at the beginning of the experiment within 200-220 g (the mean body weight: $210 \pm$ $\pm 10 \mathrm{~g}$ ). The animals were kept in lighted and ventilated conditions with room temperature and maintained day and night rhythm. The animals had a free access to standard granulated chow and drinking water was available. All the experiments were performed at the same time of the day. Procedures involving the animals and their care were conducted in conformity with the institutional guidelines that were in compliance with national and international law and with guidelines for the use of animals in biomedical research. The experimental rats were divided into two groups: $\mathrm{SH}$ - five animals underwent a sham operation and experimental uraemic group, $\mathrm{U}-$ ten rats with experimentally induced uraemia according to the method described by Ormord and Miller: surgical resection of one kidney and removal of $70 \%$ of the other kidney cortex.

\section{Method of experimental material collection and fixation}

After 4 weeks from the surgery, the rats were anesthetised by pentobarbital, administered intraperitoneally (i.p.) at a dose of $50 \mathrm{mg} / \mathrm{kg}$ and blood was collected from their hearts. Then, the animals were sacrificed by decapitation. The pancreas was immediately removed. For microscopic analysis segments of the pancreatic distal parts were used, fixed in Bouin's fluid and embedded in paraffin in the routine way. The specimens were cut into $4 \mu \mathrm{m}$ slices (Leica 2025 Autocut) and stained by haematoxylin and eosin $(\mathrm{H}+\mathrm{E})$ for general histological examination. 


\section{Determination of urea and creatinine levels} in blood serum

Blood was collected from the heart for coagulation. Collected blood samples were left for $20 \mathrm{~min}$ in room temperature to coagulate. Then, the cylinders with coagulated blood were centrifuged at 3000 RPM for $15 \mathrm{~min}$. In the blood serum obtained, urea and creatinine levels were measured in a Backman-CX4 Analyser, using an "Urée cinetique UV 800" of BioMérieux.

\section{Immunohistochemical procedure}

Immunohistochemical reactions against $\mathrm{CB} 1, \mathrm{CB} 2$, insulin, glucagon were performed on $4 \mu \mathrm{m}$ paraffin sections, obtained from the pancreas of the studied animals.

Briefly: Sections were deparaffinised and hydrated with pure ethanol. In the immunohistochemical study, the EnVision method was used according to Herman and Elfont [16]. Antigen retrieval is recommended before commencing IHC staining: for glucagon is Target Retrieval Solution (S1700; Dako, Denmark), and for CB-1 and CB-2 is Target Retrieval Solution $\mathrm{pH}=9.0$ (S2367; Dako, Denmark). Tissues were blocked in Peroxidase Blocking Reagent (S2001 Dako Denmark A/S, Produktionsvej 42, DK-2600 Glostrup) for $10 \mathrm{~min}$ at room temperature. Sections were incubated in humidified chamber with dilution primary antibodies: insulin 1:100 (A0564 Dako) and glucagon 1:200 (A0565 Dako) (30 min RT); CB-1 (ab23703 ABCAM) $1: 200$ and CB-2 (ab3561 ABCAM) 1:2000 (24hin $+4^{\circ} \mathrm{C}$ ). HRPpolymerKIT(EnVision(+) HRPpolymer anti-rabbit K 4011 Dako Denmark A/S, Produktionsvej 42, DK-2600 Glostrup) was used as the secondary antibody followed by colorimetric detection using chromogen DAB. Sections were counterstained with haematoxylin QS (Vector) and dehydrated with pure ethanol and xylene to prepare for mounting.

\section{Quantitative analysis}

The analysis of the preparations and their photographic documentation were performed using an Olympus BX41 microscope with a digital camera (Olympus DP12) and standard morphometric programme (NIS-Elements Advanced Research software of Nikon) installed on a computer. Ten randomly selected islets in each section were chosen, at a magnification $200 \times(20 \times$ the lens and $10 \times$ the eyepiece) for further morphometric analysis. The intensity of immunohistochemical reactions for each antibody was analysed. Intensity of immunohistochemical reaction was meas-
Table 1. Serum concentrations of creatinine and urea in control and uraemic rats

\begin{tabular}{lccc}
\hline & Control & Uraemic & P \\
\hline Creatinine $[\mathrm{mg} / \mathrm{dL}]$ & $0.52 \pm 0.052$ & $0.72 \pm 0.12$ & $<0.05$ \\
Urea $[\mathrm{mg} / \mathrm{dL}]$ & $35.33 \pm 5.98$ & $85.58 \pm 9.766$ & $<0.05$ \\
\hline
\end{tabular}

ured by using 0 to 256 grey scale levels, where a completely black pixel got a value of 0 , whereas one with a value of 256 is completely white or bright.

\section{Ethical issues}

Study assumptions, aim, schedule and mode of animal treatment were approved by the Senate Committee for Supervision of Experiments on Humans and Animals, Medical University of Bialystok.

\section{Statistical analysis}

The analysis was performed using the Statistica Version 10.0 programme. Results are expressed as means \pm standard deviation. The corresponding mean values were computed automatically; significant differences were determined by Student's t-test; $p<0.05$ was taken as the level of significance.

\section{RESULTS}

Serum creatinine and urea levels in rats subjected to unilateral nephrectomy and partial decortication of the other kidney were significantly increased in experimental animals in comparison to the values of those parameters in control rats (Table 1 ).

Routine $\mathrm{H}+\mathrm{E}$ staining tests have revealed differences in islet morphology between both groups. In uraemic rats, the pancreatic isles have a larger surface area and a more irregular shape compared to rats with normal renal function (Fig. 1A, B).

$A$ representative image of $C B 1$-negative control (Fig. 2). All negative controls were similar. In each case omission of the primary antibody in immunohistochemical staining resulted in a lack of reaction.

A positive reaction to $C B 1$ and $C B 2$ receptors was observed in the majority of pancreatic islet cells of all tested rats. The intensity of immunoreaction and distribution of these receptors were different in particular groups of animals.

In control rats, strong or very strong immunoreactivity against CB1 receptors was observed throughout the islets of Langerhans. In the pancreas of rats with renal insufficiency, the intensity of the CB1-positive 


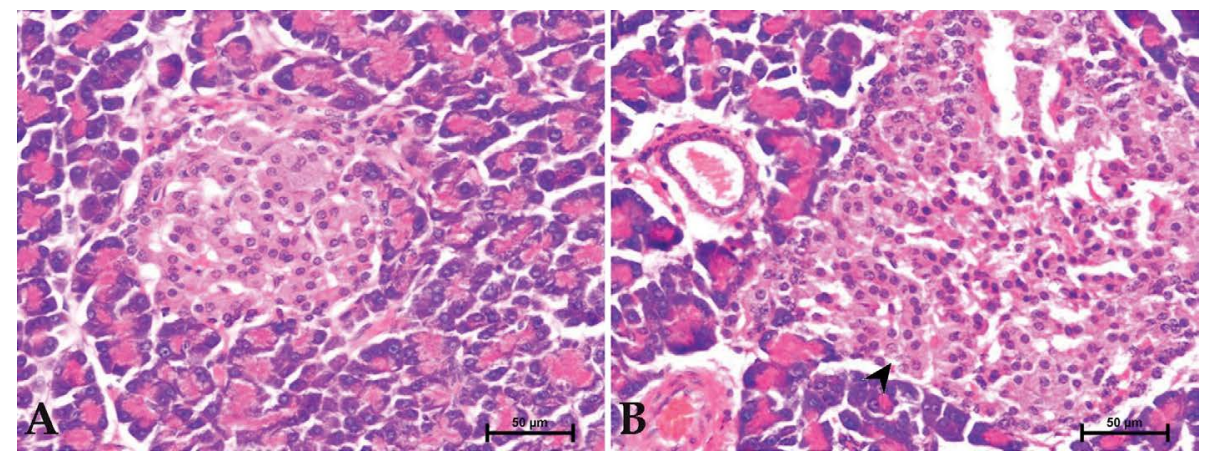

Figure 1. Photomicrographs of pancreatic islet of control rat (A), uraemic rat (arrow head) (B) (original magnification $\times 200$ ); haematoxylin and eosin stain.

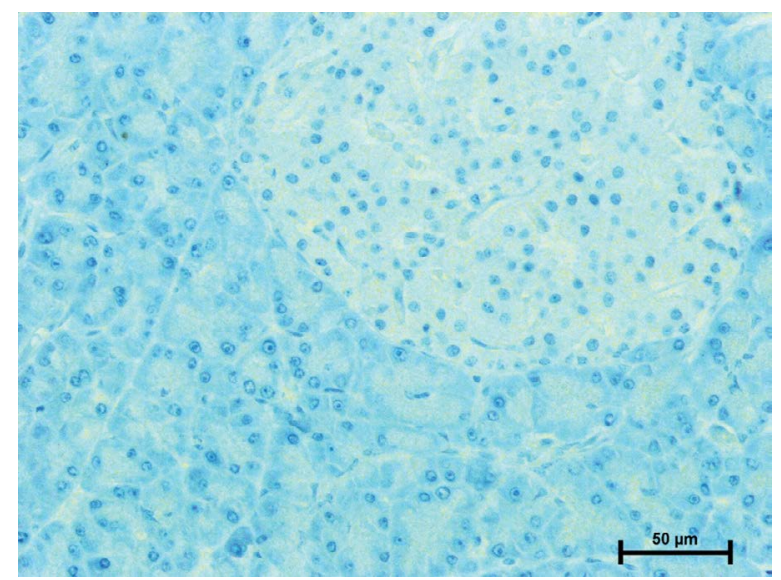

Figure 2. Representative image of negative control reaction. Lack of reaction after omission of the primary antibody in immunohistochemical procedure (original magnification $\times 200$ ). reaction was significantly weaker compared to the control animals and the density of $C B 1$ receptors was higher on islets circumference (Fig. 3A, B).

The use of an anti-CB2 antibody resulted in a very weak or marginal reaction in the pancreas of control rats (Fig. 4A). The result of the CB2-positive reaction was significantly greater in the pancreas of uraemic rats. Some cells in the central parts of uraemic rats' pancreatic islets showed moderate or strong immunoreactivity against CB2 (Fig. 4B).

Immunohistochemical tests showed a typical arrangement of insulin- and glucagon-producing cells in all the examined rats. Insulin-positive cells were observed over the entire surface of the pancreatic islets (Fig. 5A, B), while glucagon-containing cells occurred primarily on islets periphery (Fig. 6A, B).
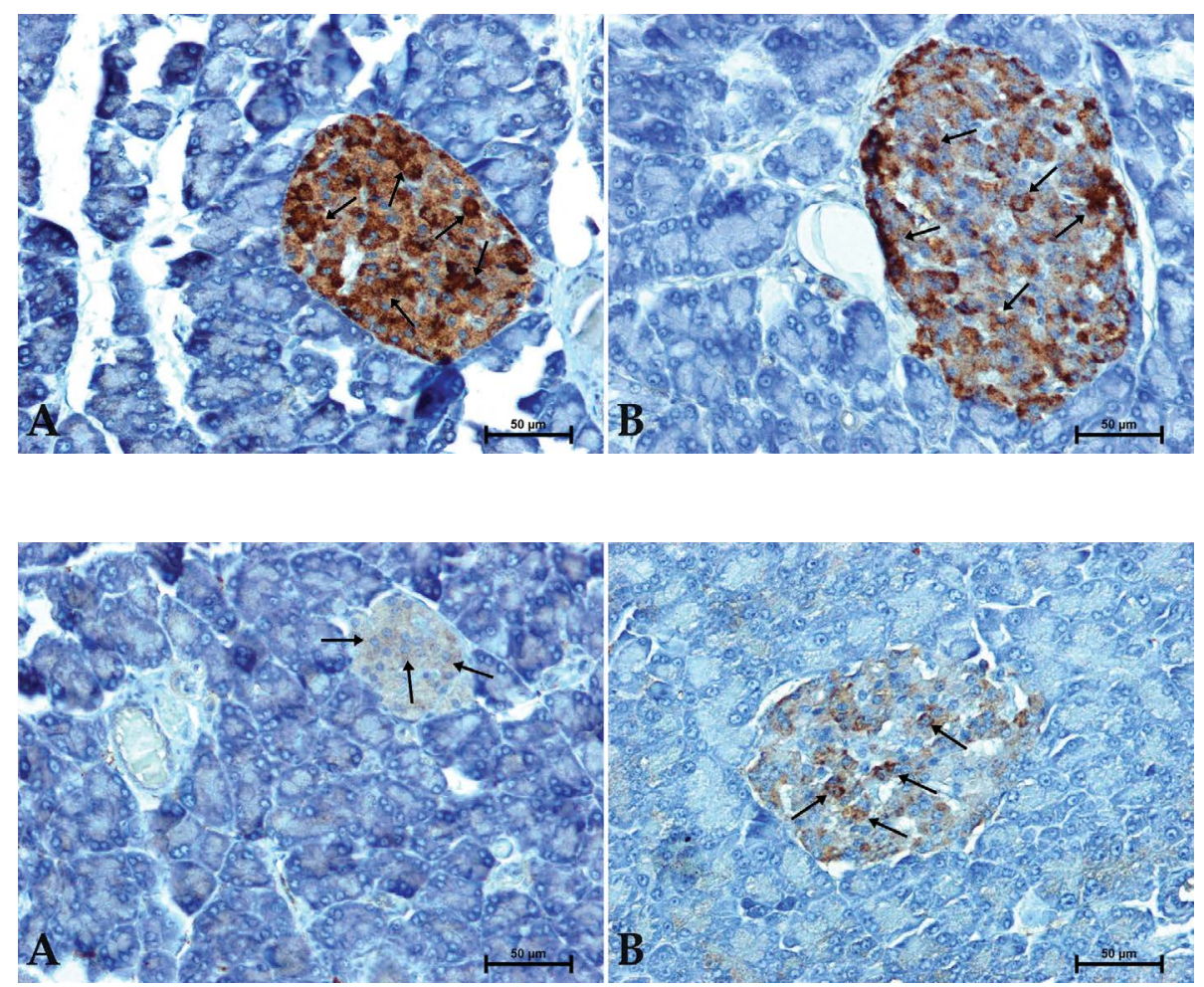

Figure 3. Immunodetection of $\mathrm{CB} 1$ receptor in pancreatic islet of control rat $(\mathbf{A})$, uraemic rat (arrows) (B) (original magnification $\times 200$ ).

Figure 4. Immunodetection of CB2 receptor in pancreatic islet of control rat (A), uraemic rat (arrows) (B) (original magnification $\times 200$ ). 

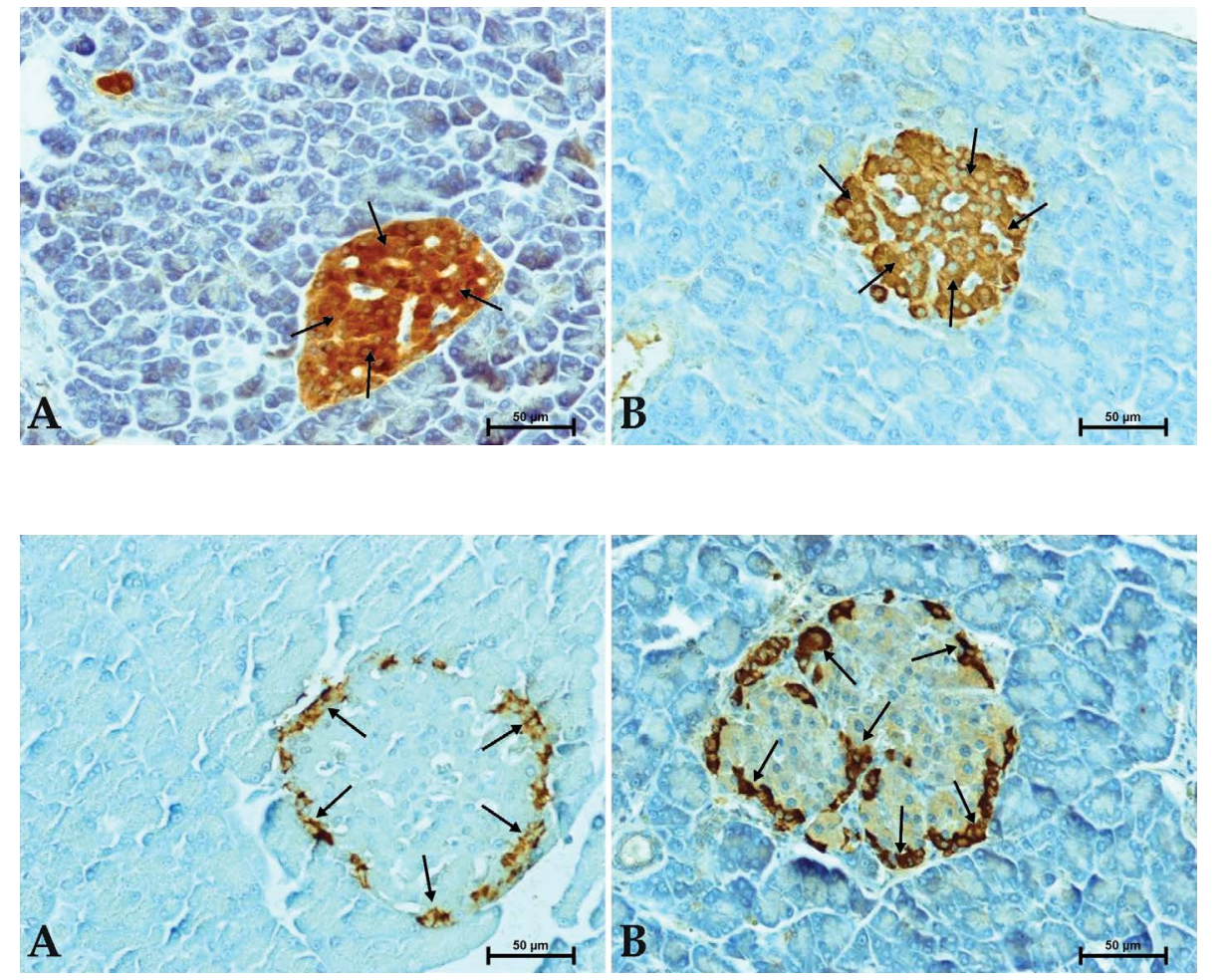

Figure 5. Immunodetection of insulin in pancreatic islet of control rat $(\mathbf{A})$, uraemic rat (arrows) (B) (original magnification $\times 200$ ).

Figure 6. Immunodetection of glucagon in pancreatic islets of control rat $(\mathbf{A})$, uraemic rat (arrows) (B) (original magnification $\times 200$ ).

Table 2. Comparative analysis of intensity of immunohistochemical reaction for $\mathrm{CB} 1, \mathrm{CB} 2$, insulin, glucagon in pancreatic islets of control and uraemic rats

\begin{tabular}{lcccc}
\hline Group & \multicolumn{4}{c}{ Intensity of immunohistochemical reaction in scale from $\mathbf{0}$ (black pixel) to 256 (white pixel) } \\
\cline { 2 - 5 } & CB1 & CB2 & Insulin & Glucagon \\
\hline Control & $53.9 \pm 2.98$ & $175.5 \pm 1.46$ & $86.3 \pm 3.7$ & $115.1 \pm 1.57$ \\
Uraemia & $104.2 \pm 3.67^{*}$ & $116.7 \pm 3.40^{*}$ & $116.1 \pm 7.07^{*}$ & $75.2 \pm 5.02^{*}$ \\
\hline
\end{tabular}

Data are shown as the mean value \pm standard deviation; ${ }^{*} p<0.05$ uraemia vs. control

The intensity of the immunohistochemical reaction revealing insulin in uraemic rats was attenuated compared to the control group (Fig. 5).

The intensity of the glucagon revealing immunoreaction in pancreatic islet $\alpha$ cells of the control group was moderate. Significantly higher immunoreactivity and an increased number of glucagon-positive cells were observed in pancreatic islets of uraemic rats (Fig. 6A, B).

Computer analysis confirmed visually observed changes in reaction intensity (Table 2 ).

\section{DISCUSSION}

The relationship between insulin-secreting $\beta$ cells and glucagon-secreting $\alpha$ cells, which work together to maintain glucose homeostasis, within the pancreatic islets is an area of extensive research. A novel component of energy regulation, endocannabinoids, has recently been identified within the endocrine part of the pancreas.

Homeostatic disorders occurring in uraemia, within a short period of time manifest themselves in the abnormal secretion of hormones and other biologically active substances. It is known that the endocannabinoid system is involved in the regulation of the energy management of the body since elements of this system occur in key peripheral tissues that control metabolism, i.e. liver, adipose tissue, muscles, and in the endocrine part of the pancreas $[2,23,33]$. Cannabinoid receptors $C B 1, C B 2$ are present in pancreatic islet cells and are involved in the regulation of hormones secreted by them $[13,22,30]$.

The aim of this study was to investigate, for the first time, the distribution of $C B 1$ and $C B 2$ cannab- 
inoid receptors as well as insulin- and glucagon-secreting cells in the pancreas of uraemic rats.

The results obtained in the experiment indicate statistically significant differences in the examined parameters in uraemic and control rats.

In this experiment, the $\mathrm{CB} 1$ and $\mathrm{CB} 2$ receptors were found to be present in the rat pancreatic islets as well as the immunoreactivity of the CB2 receptor was significantly lower than that of CB1. Likewise, other experimental studies conducted by Bermúdez-Silva et al. [6] also have demonstrated presence of $\mathrm{CB} 1$ and CB2 receptor immunoreactivity in endocrine pancreas of male Wistar rats.

Our study demonstrated diminished immunoreactivity of the CB1 receptor in uraemic rats in comparison to controls. The CB1 receptor density was higher at the periphery of the pancreatic islets in the examined rats whereas the intensity of the immunohistochemical reaction against the CB2 receptor was significantly higher in single pancreatic islet cells in uraemic rats. Considering that in the current literature there is lack of reports concerning evaluation of cannabinoid receptors in pancreas in uraemia, the discussion is quite difficult.

Several studies show that the effects of activation or blockade, as well as the distribution of cannabinoid receptors in humans and in rats, are very similar $[5,6$, $7,11,22$ ]. Laychock et al. [22] showed an increase in insulin secretion in isolated rat pancreatic islets after the administration of $\Delta$-9-tetrahydrocannabinol [22]. Bermúdez-Silva et al. [7] observed an increase in insulin as well as glucagon secretion in human pancreatic islets after the administration of a CB1 receptor agonist. In contrast, CB2 receptor stimulation reduced insulin secretion [7]. Getty-Kaushik et al. [13] found decreased insulin secretion in pancreatic islets of obese Zucker and Zucker Diabetic Fatty rats treated with a CB1 receptor antagonist.

The decrease in the $\mathrm{CB} 1$ receptor immunoreactivity observed in the present study in the central part of the islets may indicate the induction of protective mechanisms in the pancreatic islets in chronic renal failure. Confirmation of this hypothesis may be found in studies conducted by Janiak et al. [17] as well as Kim et al. [19]. Janiak et al. [17] used a CB1 receptor antagonist and observed the preservation of pancreatic weight and $\beta$ cell mass in obese Zucker rats. Kim et al. [19] found that the blockade or genetic deficiency in the $\mathrm{CB} 1$ receptor increases the survival of $\beta$ cells in mice following the administration of streptozotocin. Other studies conducted by Lin et al. [24] demonstrated that blockade of CB1R by treatment with CB1R antagonist attenuates the left ventricular hypertrophy and Akt-mediated cardiac fibrosis in chronic kidney disease mouse model. On the other hand, Bátkai et al. [4] showed protective role of CB2 receptor activation in hepatic ischae$\mathrm{mia} /$ reperfusion injury in mice. Similar observations were made by Montecucco et al. [27] in hearts from a mouse model of ischaemia/reperfusion. It is known that chronic kidney disease leads to increase in number of different substances provoking cell damage and apoptosis therefore observed decrease in CB1 receptor and increase in CB2 immunoreactivity may be one of the possible adaptation processes aimed at limiting pancreatic islet cell destruction.

In the pancreas of uraemic rats, lower intensity of the insulin-positive reaction as well as stronger immunoreactivity of glucagon-positive cells were observed. Hyperglucagonaemia in chronic renal failure is a phenomenon that has been repeatedly mentioned in various reports $[8,9,12,31]$. The results of studies conducted by Koppe et al. [20] show defective insulin secretion caused by the direct action of urea on $\beta$ cells. On the other hand, insulin resistance which develops during chronic renal failure also has a profound effect on the function of endocrine cells in the pancreatic islets [10, 21, 32, 36].

Several reports published to date illustrate that CB1 receptor antagonists have an inhibitory effect on insulin secretion $[7,10,13]$. Considering the information presented above and the results of our own research, it can be assumed that there may be $\mathrm{CB} 1$ blocking agents in chronic renal failure. However, changes observed in our study may be the result of a number of different mechanisms and it is difficult to explain them at this stage since the body of knowledge regarding this issue is limited.

\section{CONCLUSIONS}

It can be concluded that uraemia leads to disorders of the insulin, glucagon production and CB1, CB2 immunoreactivity in the pancreatic islets as well as larger surface area and a more irregular shape of pancreatic islets in uraemic rats compared to rats with normal renal function. That suggests the involvement of cannabinoid receptors in the pathomechanism of carbohydrate metabolism disorders in chronic kidney disease.

The results of our studies can contribute to a better understanding of the changes occurring in 
the endocrine part of the pancreas in uraemia as well as inspire other scientists to conduct research involving this important issue.

\section{REFERENCES}

1. Anderson RL, Randall MD, Chan SLF. The complex effects of cannabinoids on insulin secretion from rat isolated islets of Langerhans. Eur J Pharmacol. 2013; 706(1-3): 56-62, doi: 10.1016/j.ejphar.2013.02.034, indexed in Pubmed: 23499687.

2. Araki T, Ueda M, Ogawa $\mathrm{K}$, et al. Histological pancreatitis in end-stage renal disease. Int J Pancreatol. 1992; 12(3): 263-269, doi: 10.1007/BF02924366, indexed in Pubmed: 1283864.

3. Baggenstoss $\mathrm{AH}$. The pancreas in uremia; a histopathologic study. Am J Pathol. 1948; 24(5): 1003-1017, indexed in Pubmed: 18883950

4. Bátkai S, Osei-Hyiaman D, Pan H, et al. Cannabinoid-2 receptor mediates protection against hepatic ischemia/reperfusion injury. FASEB J. 2007; 21(8): 1788-1800, doi: 10.1096/fj.067451 com, indexed in Pubmed: 17327359.

5. Bermúdez-Siva FJ, Serrano A, Diaz-Molina FJ, et al. Activation of cannabinoid CB1 receptors induces glucose intolerance in rats. Eur J Pharmacol. 2006; 531(1-3): 282-284, doi: 10.1016/j. ejphar.2005.12.016, indexed in Pubmed: 16423347.

6. Bermudez-Silva FJ, Sanchez-Vera I, Suárez J, et al. Role of cannabinoid CB2 receptors in glucose homeostasis in rats. Eur J Pharmacol. 2007; 565(1-3): 207-211, doi: 10.1016/j. ejphar.2007.02.066, indexed in Pubmed: 17499236.

7. Bermúdez-Silva FJ, Suárez J, Baixeras E, et al. Presence of functional cannabinoid receptors in human endocrine pancreas. Diabetologia. 2008; 51(3): 476-487, doi: 10.1007/s00125007-0890-y, indexed in Pubmed: 18092149.

8. Bilbrey GL, Faloona GR, White MG, et al. Hyperglucagonemia of renal failure. J Clin Invest. 1974; 53(3): 841-847, doi: 10.1172/ $\mathrm{JCl} 107624$, indexed in Pubmed: 4812442.

9. DeFronzo RA, Andres R, Edgar P, et al. Carbohydrate metabolism in uremia: a review. Medicine (Baltimore). 1973; 52(5): 469-481, doi: 10.1097/00005792-197309000-00009, indexed in Pubmed: 4579981.

10. Després JP, Golay A, Sjöström L, et al. Rimonabant in Obesity-Lipids Study Group. Effects of rimonabant on metabolic risk factors in overweight patients with dyslipidemia. N Engl J Med. 2005: 353(20): 2121-2134, doi: 10.1056/NEJMoa044537, indexed in Pubmed: 16291982.

11. Duvivier VF, Delafoy-Plasse L, Delion V, et al. Beneficial effect of a chronic treatment with rimonabant on pancreatic function and beta-cell morphology in Zucker Fatty rats. Eur J Pharmacol. 2009; 616(1-3): 314-320, doi: 10.1016/j.ejphar.2009.05.024, indexed in Pubmed: 19482020.

12. Emmanouel DS, Lindheimer MD, Katz Al. Pathogenesis of endocrine abnormalities in uremia. Endocr Rev. 1980; 1(1): 28-44, doi: 10.1210/edrv-1-1-28, indexed in Pubmed: 6785085.

13. Getty-Kaushik L, Richard AMT, Deeney JT, et al. The CB1 antagonist rimonabant decreases insulin hypersecretion in rat pancreatic islets. Obesity (Silver Spring). 2009; 17(10): 1856-1860, doi: 10.1038/oby.2009.234, indexed in Pubmed: 19644453.

14. González-Mariscal I, Egan JM. Endocannabinoids in the Islets of Langerhans: the ugly, the bad, and the good facts. Am J Physiol Endocrinol Metab. 2018; 315(2): E174-E179, doi: 10.1152/ajpendo.00338.2017, indexed in Pubmed: 29631361.

15. Hager SR. Insulin resistance of uremia. Am J Kidney Dis. 1989; 14(4): 272-276, doi: 10.1016/s0272-6386(89)80201-x, indexed in Pubmed: 2679057.

16. Herman GE, Elfont EA. The taming of immunohistochemistry: the new era of quality control. Biotech Histochem. 1991; 66(4): 194-199, doi: 10.3109/10520299109109968, indexed in Pubmed: 1912080.

17. Janiak P, Poirier B, Bidouard JP, et al. Blockade of cannabinoid CB1 receptors improves renal function, metabolic profile, and increased survival of obese Zucker rats. Kidney Int. 2007; 72(11): 1345-1357, doi: 10.1038/sj.ki.5002540, indexed in Pubmed: 17882151.

18. Juan-Picó $P$, Fuentes $E$, Bermúdez-Silva FJ, et al. Cannabinoid receptors regulate $\mathrm{Ca}(2+)$ signals and insulin secretion in pancreatic beta-cell. Cell Calcium. 2006; 39(2): 155-162, doi: 10.1016/j.ceca.2005.10.005, indexed in Pubmed: 16321437.
19. Kim W, Lao Q, Shin YK, et al. Cannabinoids induce pancreatic $\beta$-cell death by directly inhibiting insulin receptor activation. Sci Signal. 2012; 5(216): ra23, doi: 10.1126/scisignal.2002519, indexed in Pubmed: 22434934.

20. Koppe L, Nyam E, Vivot $K$, et al. Urea impairs $\beta$ cell glycolysis and insulin secretion in chronic kidney disease. J Clin Invest. 2016; 126(9): 3598-3612, doi: 10.1172/JCI86181, indexed in Pubmed: 27525435.

21. Koppe L, Pelletier CC, Alix PM, et al. Insulin resistance in chronic kidney disease: new lessons from experimental models. Nephrol Dial Transplant. 2014; 29(9): 1666-1674, doi: 10.1093/ndt/ gft435, indexed in Pubmed: 24286973.

22. Laychock SG, Hoffman JM, Meisel $E$, et al. Pancreatic islet arachidonic acid turnover and metabolism and insulin release in response to delta-9-tetrahydrocannabinol. Biochem Pharmacol. 1986; 35(12): 2003-2008, doi: 10.1016/0006-2952(86)90733-1, indexed in Pubmed: 3013206.

23. Li C, Jones PM, Persaud SJ. Role of the endocannabinoid system in food intake, energy homeostasis and regulation of the endocrine pancreas. Pharmacol Ther. 2011; 129(3): 307-320, doi: 10.1016/j. pharmthera.2010.10.006, indexed in Pubmed: 21055418.

24. Lin CY, Hsu YJ, Hsu SC, et al. CB1 cannabinoid receptor antagonist attenuates left ventricular hypertrophy and Akt-mediated cardiac fibrosis in experimental uremia. J Mol Cell Cardiol. 2015; 85: 249-261, doi: 10.1016/j.yjmcc.2015.06.010, indexed in Pubmed: 26093151.

25. Malenczyk K, Keimpema E, Piscitelli F, et al. Fetal endocannabinoids orchestrate the organization of pancreatic islet microarchitecture. Proc Natl Acad Sci U S A. 2015; 112(45): E6185-E6194, doi: 10.1073/pnas.1519040112, indexed in Pubmed: 26494286.

26. Matias I, Gonthier MP, Orlando P, et al. Regulation, function, and dysregulation of endocannabinoids in models of adipose and beta-pancreatic cells and in obesity and hyperglycemia. J Clin Endocrinol Metab. 2006; 91(8): 3171-3180, doi: 10.1210/ jc. 2005-2679, indexed in Pubmed: 16684820.

27. Montecucco F, Lenglet S, Braunersreuther $\mathrm{V}$, et al. $\mathrm{CB}(2)$ cannabinoid receptor activation is cardioprotective in a mouse model of ischemia/reperfusion. J Mol Cell Cardiol. 2009; 46(5): 612-620, doi: 10.1016/j.yjmcc.2008.12.014, indexed in Pubmed: 19162037.

28. Nakata M, Yada T. Cannabinoids inhibit insulin secretion and cytosolic $\mathrm{Ca} 2+$ oscillation in islet beta-cells via CB1 receptors. Regul Pept. 2008; 145(1-3): 49-53, doi: 10.1016/j. regpep.2007.08.009, indexed in Pubmed: 17884194.

29. Neirynck N, Vanholder R, Schepers E, et al. An update on uremic toxins. Int Urol Nephrol. 2013; 45(1): 139-150, doi: 10.1007/ s11255-012-0258-1, indexed in Pubmed: 22893494

30. Polak A, Harasim E, Chabowski A. Effects of activation of endocannabinoid system on myocardial metabolism. Postepy Hig Med Dosw (Online). 2016; 70(0): 542-555, doi: 10.5604/17322693.1202483, indexed in Pubmed: 27333924.

31. Sherwin RS, Bastl C, Finkelstein FO, et al. Influence of uremia and hemodialysis on the turnover and metabolic effects of glucagon. J Clin Invest. 1976; 57(3): 722-731, doi: 10.1172/ JCl108330, indexed in Pubmed: 1249205.

32. Silvestri C, Di Marzo V. The endocannabinoid system in energy homeostasis and the etiopathology of metabolic disorders. Cell Metab. 2013; 17(4): 475-490, doi: 10.1016/j. cmet.2013.03.001, indexed in Pubmed: 23562074.

33. Vanholder R, De Smet R, Glorieux G, et al. Review on uremic toxins: classification, concentration, and interindividual variability. Kidney Int. 2003; 63(5): 1934-1943, doi: 10.1046/j.15231755.2003.00924.x, indexed in Pubmed: 12675874.

34. Vilches-Flores A, Delgado-Buenrostro NL, Navarrete-Vázquez G, et al. CB1 cannabinoid receptor expression is regulated by glucose and feeding in rat pancreatic islets. Regul Pept. 2010; 163(1-3): 81-87, doi: 10.1016/j.regpep.2010.04.013, indexed in Pubmed: 20451564.

35. Wang PF, Jiang LS, Bu J, et al. Cannabinoid-2 receptor activation protects against infarct and ischemia-reperfusion heart injury. J Cardiovasc Pharmacol. 2012; 59(4): 301-307, doi: 10.1097/ FJC.0b013e3182418997, indexed in Pubmed: 22113346.

36. $\mathrm{Xu} \mathrm{H}$, Carrero JJ. Insulin resistance in chronic kidney disease. Nephrology (Carlton). 2017; 22 Suppl 4: 31-34, doi: 10.1111/ nep.13147, indexed in Pubmed: 29155496. 